\title{
Lancelot Brown, His Majesty's Chief Gardener at Hampton Court
}

\author{
David Jacques
}

Lancelot Brown's career as His Majesty's Chief Gardener at Hampton Court has been less researched than his contracting business. This chapter looks at Lancelot Brown in that capacity and resolves most of the numerous confusions surrounding his involvement at other royal properties.

\section{How the Royal Gardens Were Run}

When Brown took up his post at Hampton Court in 1764, the Board of Works was, even by the government standards of the day, notoriously riddled with placemen who added nothing to the effectiveness of the institution but cost a great deal. The four senior posts were that of Surveyor-General, Surveyor of Gardens and Waters, Surveyor of the King's Private Roads, and Paymaster. These placeholders were mostly Members of Parliament enjoying their positions as sinecures. Thomas Worsley (1710-78), Surveyor-General, happened to be an amateur architect and conscientiously took an interest in the work of the Board, though this was not demanded of him. His successor in 1778, Colonel Whitshed Keene (1731-1822), reverted to type. Below the senior posts, the Comptroller of Works and the Chief Gardeners were required to be experienced professionals. The first Surveyor of Gardens and Waters, in 1715, John Vanbrugh, had carried out his duties, but his successors treated the post as a sinecure worth $£ 500$. At the point when Brown took up post, his nominal supervisor was Charles Sloane Cadogan (1728-1807), the Whig MP for Cambridge until 1776, when he succeeded as $3^{\text {rd }}$ Baron Cadogan. His sinecures had begun with Keeper of the Privy Purse to Prince Edward in 1756; he advanced to Surveyor of Gardens and Waters from 1764 to 1769 on an increased salary of $£ 800$; $^{1}$ finally he was Master of the Mint from 1769 to 1784. Cadogan was succeeded as Surveyor of Gardens and Waters in 1769 by William Varey (1711-93), of Ixworth Abbey, Suffolk, about whom very little is known. ${ }^{2}$

The Paymaster was George Augustus Selwyn (1719-91), of Matson, Gloucestershire. He became a Tory MP in 1747 and acquired a number of sinecures, being appointed to the post of Paymaster of the Works in 1755.

1 The National Archives (TNA), WORK 6/8, ff 219-221 \& 223.

2 TNA, WORK 6/8, ff 242-244 \& 252.

How to cite this book chapter:

Jacques, D. 2020. Lancelot Brown, His Majesty's Chief Gardener at Hampton Court. In Finch, J. and Woudstra, J. (Eds.), Capability Brown, Royal Gardener: The business of place-making in Northern Europe, pp. 17-31. York: White Rose University Press. DOI: https://doi.org/10.22599/CapabilityBrown.b. CC BY-NC 4.0 
Famous as a wit and man of letters, and for his fascination for the macabre, his workload consisted mainly of dining with the officers at the public expense. ${ }^{3}$ The abuses of public finance came under scrutiny by the Rockingham Whigs, in particular Edmund Burke, whose speech, 'On The Plan For Economical Reform', in 1780 was highly influential. Sinecures were abolished by the Civil Establishment Act 1782 and the Office of Works was placed under the jurisdiction of the Lord Chamberlain. The Office was also reorganised: the post of Surveyor-General (Keene) and Comptroller were amalgamated in the person of Sir William Chambers, whilst the Surveyorship of Gardens and Waters (Varey), the Surveyorship of the King's Private Roads and the Paymaster (Selwyn) were abolished.

\section{Brown Seeking Royal Patronage}

After Thomas Greening junior died in 1757, his brother Robert composed a letter to Lord Hardwicke, hoping that he would mention him favourably to the Duke of Newcastle, the Prime Minister at the time. ${ }^{4} \mathrm{He}$ added that he had heard 'that Mr. Brown was an applicant'. That was indeed the case, for in March 1758 fourteen of Lancelot Brown's clients, including the Duke of Northumberland and the Lords Temple, Egremont, Ancaster, Exeter, and Hertford (at Syon, Wotton, Petworth, Grimsthorpe, Burghley, and Croome, respectively), put forward the well-known petition:

We whose Names are underwritten, being well-wishers of Mr. Browne, whose Abilities and Merit we are fully acquainted with, do most earnestly request the Duke of Newcastle to promote his speedy appointment to the care of Kensington Gardens agreeable to his Grace's very obliging promises in this respect...

However, the Greenings prevailed and Robert and his brother John were appointed to the post (see Chapter 9), leaving Brown to ponder how he could secure a royal appointment whilst the Duke, and then Lord Bute, had their own favourites.

George III purchased Buckingham House, now Buckingham Palace, in 1761 as a property for his queen, renaming it 'The Queen's House', and remodelling began in early 1762 under the direction of two recent appointees, William Chambers, Architect to the Board of Works, and William Robinson, Secretary to the Board, as Clerk of Works. Brown hoped for a private commission in the gardens. A survey of the old gardens exists, as do two unsigned and undated designs, probably prepared in or around $1762 .{ }^{6}$ The flowing curves of the paths, the heavy peripheral planting and the specimen trees in the grassland suggest Brown's hand (Figure 2.1). These plans have sometimes led to the assumption that the Queen's House gardens were by Brown, but the implemented layout was in fact quite different.

Brown was not given care of the gardens either - that task went to Thomas Robinson from 1762. He was being promoted by his elder brother William, the Secretary to the Board of Works, and other members of it. Although John Hill, the botanist and favourite of Lord Bute, had displaced John Greening at Kensington Gardens and St. James's Palace, he was never issued a warrant. In the confusion when Hill abandoned his post in 1763, Robinson was put in charge of these gardens as well, and was later to establish that de facto he had been looking after Kensington and St. James's as from January 1763, and he was officially made Chief Gardener there in $1766 .^{7}$ Robinson received quarterly payments for the Queen's House gardens until 1777, when he was prevailed upon to accept the post of Chief Gardener at an annual salary. ${ }^{8}$ One interesting aspect of his 'scheme' was that he managed a herd of cattle and a flock of sheep that he moved back and forth between the Queen's House and Kensington Gardens.

Cahier XX of Georges-Louis le Rouge's Jardins Anglo-Chinois (1788), which is confirmed by Richard Horwood's A Plan of the Cities of London and Westminster (1794), shows a much simpler design of a ferme ornée, and it is this that tallies with the archive (Figure 2.2). It had merely a perimeter belt with more wavering paths than those on Brown's plan, and a sunken fence enclosed a paddock, which was twenty-five of the

\footnotetext{
${ }^{3}$ His correspondence was later published. Jesse, J. H. (1843). George Selwyn and his contemporaries. London: Richard Bentley.

${ }^{4}$ British Library, Add. 35595 f 80: Robert Greening to the Earl of Hardwicke, 3 September 1757.

${ }^{5}$ Stroud, D. (1975). Capability Brown (pp. 121-122). London: Faber and Faber.

${ }^{6}$ Royal Library, Windsor, RL 29592, RL 29593 \& RL 29594.

7 TNA, WORK 4/13, 7 March 1766.

8 TNA, WORK 6/8, ff 263-236, 10 March 1777.
} 


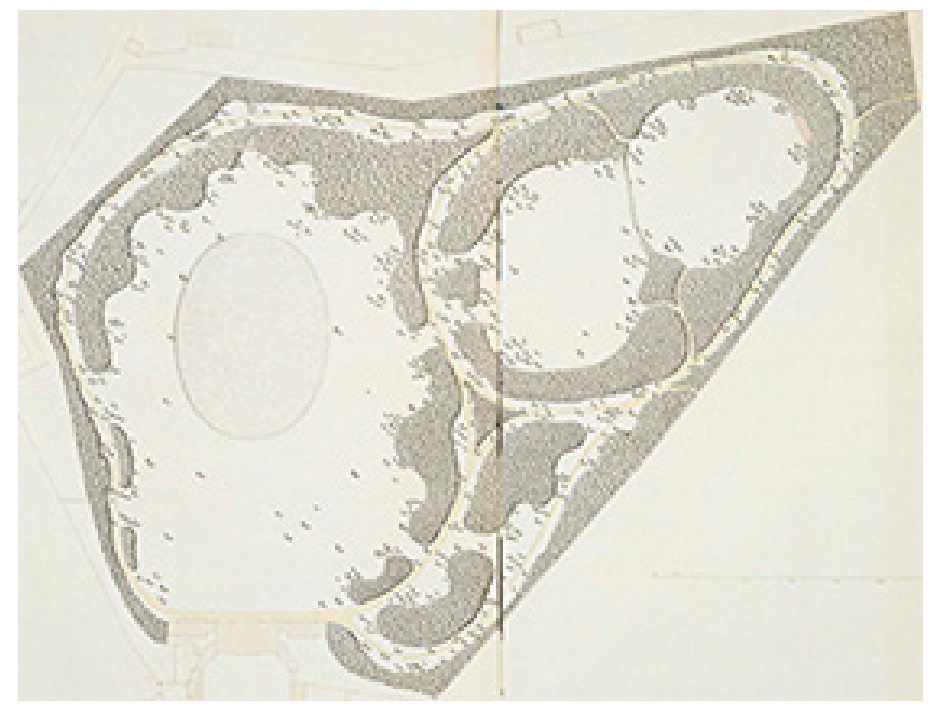

Figure 2.1: Buckingham Palace gardens, Lancelot 'Capability' Brown (attributed), c. 1762. Royal Collection Trust / @ Her Majesty Queen Elizabeth II 2019.

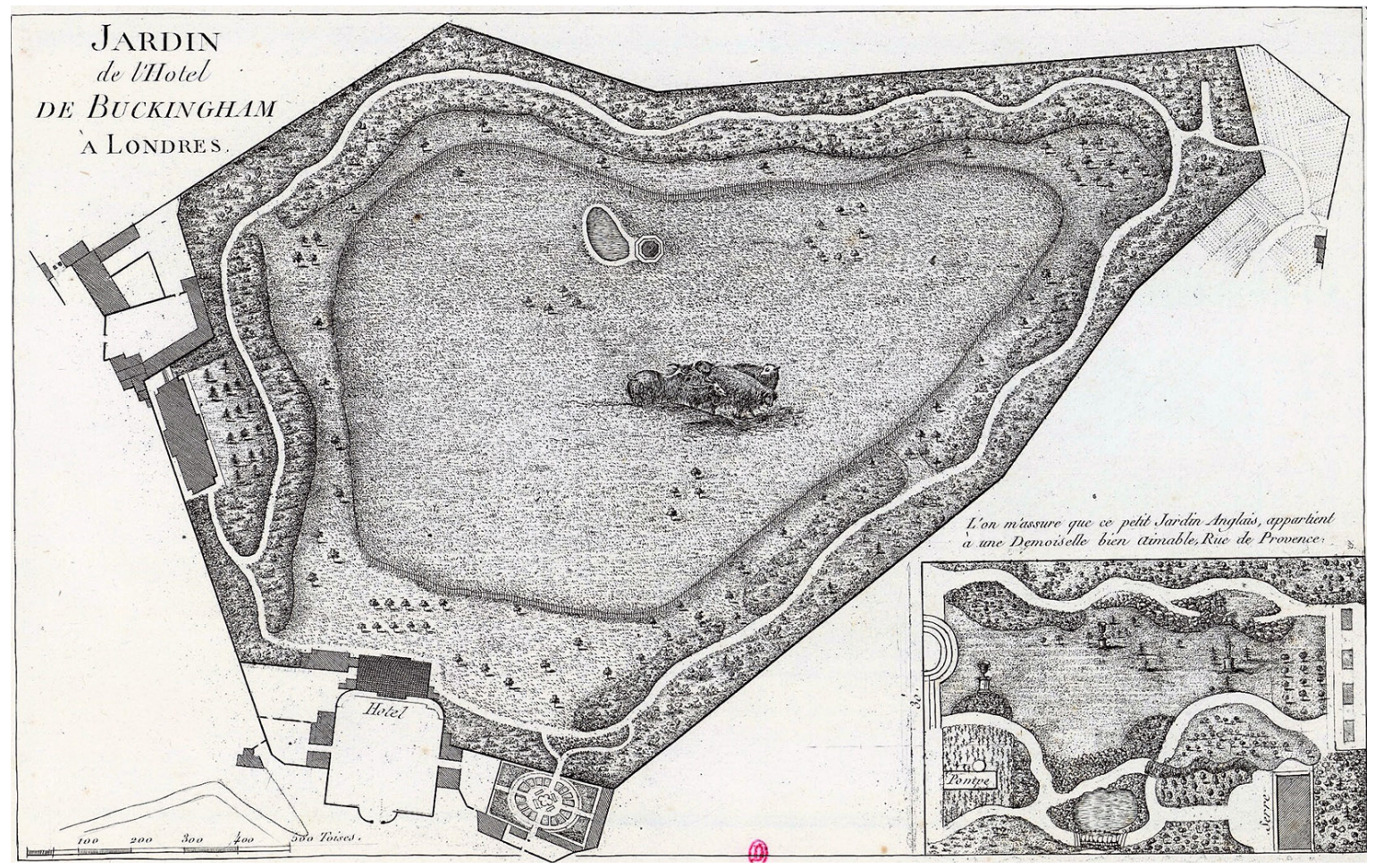

Figure 2.2: 'Jardin de l'Hotel de Buckingham à Londres', in Jardins Anglo-Chinois à la Mode (plate XX), Georges-Louis le Rouge, 1788. Source: Bibliothèque nationale de France. Reproduced with permission. 


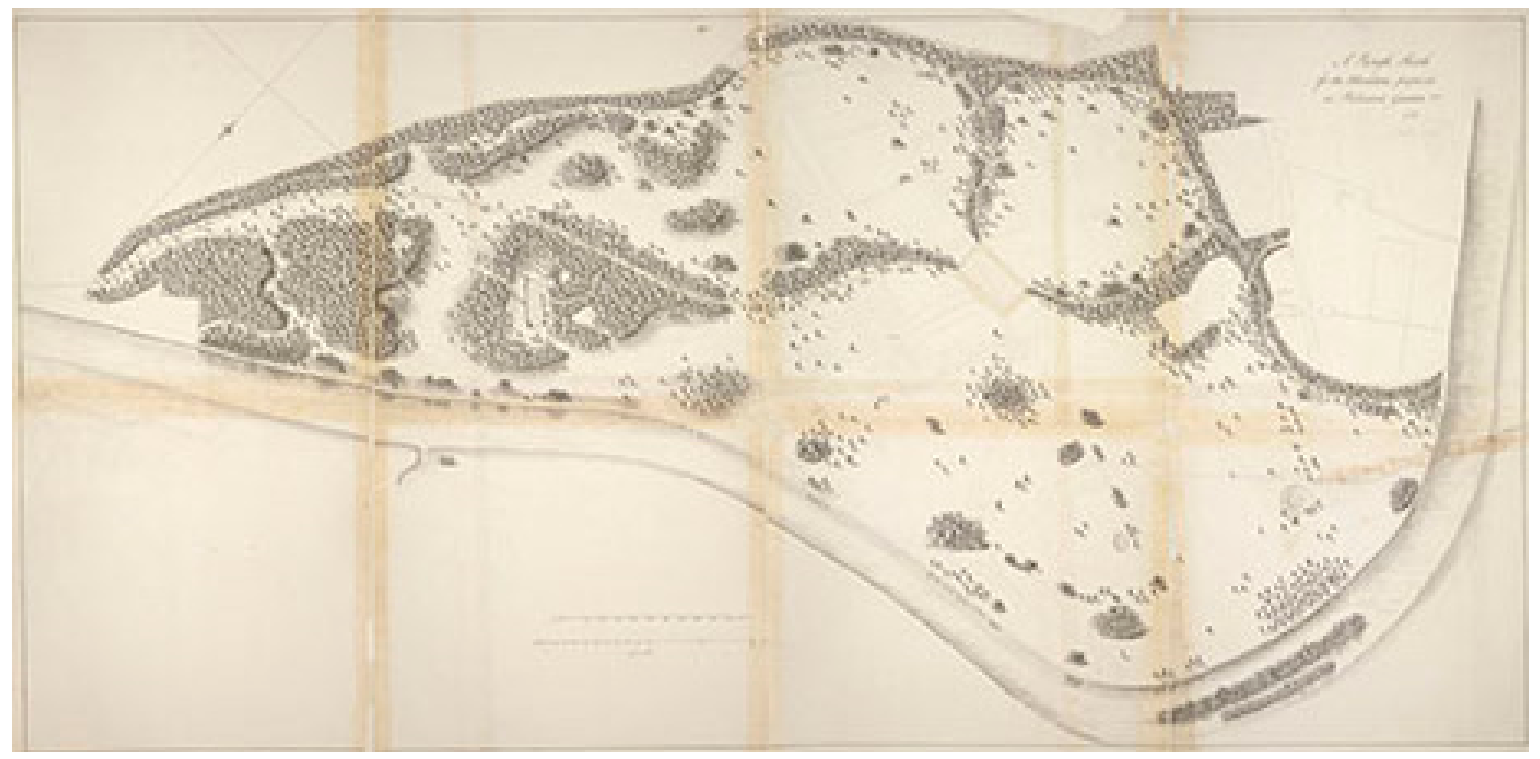

Figure 2.3: A rough sketch for the alterations proposed in Richmond Garden, \&c., Lancelot 'Capability' Brown (attributed), c. 1764. Royal Collection Trust / @ Her Majesty Queen Elizabeth II 2019.

forty-five acres. ${ }^{9}$ The paddock was where the queen kept her Kashmiri goats. An oval flower garden with a central quatrefoil pool was made close to the house.

This ferme ornée layout shows marked similarities to the plan of Kew Gardens. The expansion of those gardens had been initiated by Prince Frederick (d. 1751), with John Dillman as head gardener. In 1753 Robert Greening (d. 1758) took over from Dillman in the making of Kew Gardens, including a sunken fence around two paddocks and an oval flower garden with a central quatrefoil pool. ${ }^{10}$ William Chambers became involved in 1757, when appointed drawing master to Prince George and designed a medley of fabriques, most famously the eclectic pagoda, erected during the early 1760s. Chambers published his Plans, Elevations, Sections and Perspective Views... of Kew dated 1763 and included a detailed plan of the gardens. Chambers referred to Bute as the 'director', and implied that he was responsible for the layout of Kew Gardens under Frederick's widow, Princess Augusta. ${ }^{11}$

Bute continued in high favour and was Prime Minister from May 1762 to April 1763, after which he withdrew from court. It seems likely that before leaving office he had determined that the layout of the Queen's House garden would follow the general design for Kew. Although it is possible that Chambers provided the layout at the Queen's House, the similarity to that for Kew, accomplished before Chambers was involved, makes this less likely. Although not successful at the Queen's House, Brown was commissioned at Richmond Gardens. A scheme to include the Old Deer Park to the north and east of Kew, dated $10^{\text {th }}$ December 1764, was prepared (Figure 2.3). ${ }^{12}$ Terms between Brown and the King must have been arrived at (although no contract has come to light), as in January 1765 Brown transferred his foreman at Chatsworth, Michael Milican, to Richmond: 'I intend employing you in his Majesty's work at Richmond. ${ }^{13}$ A few weeks later Milican wrote to his wife, still at Chatsworth: 'I am now settled as Foreman in his Majesty's works at Richmond where the worke will last for many years'.

The alterations by Brown were certainly under way in early 1765. Merlin's Cave, designed by William Kent in 1735, was demolished that year and the lead from its roof sold. Brown remarked to a Treasury official in 1766: 'I would have waited on you my self but Tuesdays \& Saturds are the Days I am expected at Richmond.'14

\footnotetext{
9 TNA, WORK 6/08, f 263.

10 Desmond, R. (1995). The history of the Royal Botanic Gardens, Kew (p. 33). Kew: Harvill Press with Royal Botanic Gardens.

11 Desmond, R. (1995). Royal Botanic Gardens (pp. 57-58).

12 Kept at the Royal Botanic Garden, Kew.

13 Stroud, D. (1975). Capability Brown (p. 126).

14 TNA, T 1/448/187-188.
} 
Brown's surviving account book, starting December 1764, contains a sheet for 'His Majesty the King. This indicated quarterly payments by George III of $£ 500$ from March 1765 until January $1777 . .^{15}$ The payments were delivered by Sir William Bretton, George Mathias, or some other member of the king's household. ${ }^{16}$ Bretton was in fact Keeper of the Privy Purse, 1763-73, so these payments to Brown were private expenditure, and no doubt for Richmond Gardens. As they had no vote for improvement from Parliament, they would thus have been improved at George III's own expense.

Chambers was meanwhile planning a new palace at Richmond. A drawing of the 'North front of a villa for a particular situation near London' was exhibited in 1762, before a model was made and presented to the king in $1765 .{ }^{17}$ Seeing Brown's work being implemented at considerable cost, whilst his own architectural dream languished, must have been irritating for Chambers. In October 1765 the Board of Works minuted that 'great alteration \& improvements are making in Richmond Gardens by Mr Launcelot Browne', and queried whether the allowance to Thomas Greening's successor, John Haverfield, should not be abated 'his having nothing to do for the present, with that part of the Garden where the alterations are making. ${ }^{18}$

\section{Chief Gardener at Hampton Court}

Shortly before the Richmond contract Brown was at last appointed one of the Royal Gardeners. After Bute's dismissal in April 1763, George III had to resort to George Grenville (1712-70), whom he personally disliked, to be Prime Minister. Grenville was younger brother to Earl Temple, a nephew of Viscount Cobham, of Stowe, and one of the new breed of Whig 'boy patriots'. Significantly, given the importance of aristocratic patronage at court, Brown would have been known to Grenville from his days at Stowe. They crossed paths at Shortgrove, Essex, in June 1764, and Grenville must have promised Brown a warrant to replace John Greening at Hampton Court. The possibility of future alterations at Windsor was apparently in Brown's mind, for he felt emboldened to write that 'I should be very happy to have the garden at Windsor Castle included in the Warrant', which would 'give me a better pretension my having the place to be employed. ${ }^{19}$ When word reached John Greening, he affected to be greatly surprised at 'this unexpected affair', and wrote to a friend that Lord Halifax, the Secretary of State, 'told me ... He went to the King and told him he was excessively sorry to hear that I was to be turned out to make way for Brown. ${ }^{20}$ The die had been cast, though, and Greening's warrant was revoked in favour of Brown. ${ }^{21}$ Greening had also been Master Labourer and Scavenger at Hampton Court and to the King's Private Roads. That position went to Robert Lowe, nephew to George Lowe, upon whose death in 1758 Greening had been appointed at Hampton Court. ${ }^{22}$ Perhaps as compensation Greening was appointed as housekeeper of the Customs House, a largely honorary position that in 1766 provided a salary of $£ 385$.

Warrants required the Treasury to provide specified allowances to the Office of Works to be passed on to the Chief Gardener. As elsewhere, the allowance for Hampton Court was $£ 15$ per acre. The fifty-seven acres of gardens at the palace, and seventeen acres at the Lower Wilderness, totalling nearly seventy-four acres (Figure 2.4), representing a sum of $£ 1,107-6 \mathrm{~s}-0 \mathrm{~d}$. There were also two allowances carried on from predecessors. Lowe had successfully petitioned for another $£ 100$ in 1741 for raising pineapples, ${ }^{23}$ and the requirement on Greening in 1758 to provide 'forced fruit' was worth another $£ 100$.

An associated 'scheme', derived from that prepared by Henry Wise in Queen Anne's reign, set out the treatment of each area and responsibilities in finding the associated tools and the replacement of dead plants at his own cost. ${ }^{24}$ Meanwhile, architectural officers in the Works were responsible for all 'hard' structures in the gardens under the Office of Works's care, including greenhouses, walls, drains, and the laying of paths, which were separately identified in the Paymaster's accounts. Checking that standards were being maintained was

\footnotetext{
${ }^{15}$ Brown, J. (2011). The omnipotent magician, Lancelot 'Capability' Brown, 1716-1783 (p. 161). London: Chatto and Windus.

${ }^{16}$ Stroud, D. (1975). Capability Brown (p. 122).

${ }_{17}$ Harris, J. (1970). Sir William Chambers (p. 243). London: Zwemmer.

18 TNA, WORK 4/13, 11 October 1765.

19 British Library, Add MS 57822-57828, fol. 155; Brown to Grenville, 22 June 1764.

20 British Library, Add MS 32960, f 50; John Greening to J. Twells, 23 June 1764.

${ }^{21}$ TNA, WORK 6/8, fol.228; Warrant, 16 July 1764.

${ }^{22}$ TNA, WORK 4/13, 11 January 1765.

${ }^{23}$ TNA, WORK 6/13, p. 41, 17 June 1741.

24 TNA, WORK 6/8, ff $230 \& 231$.
} 


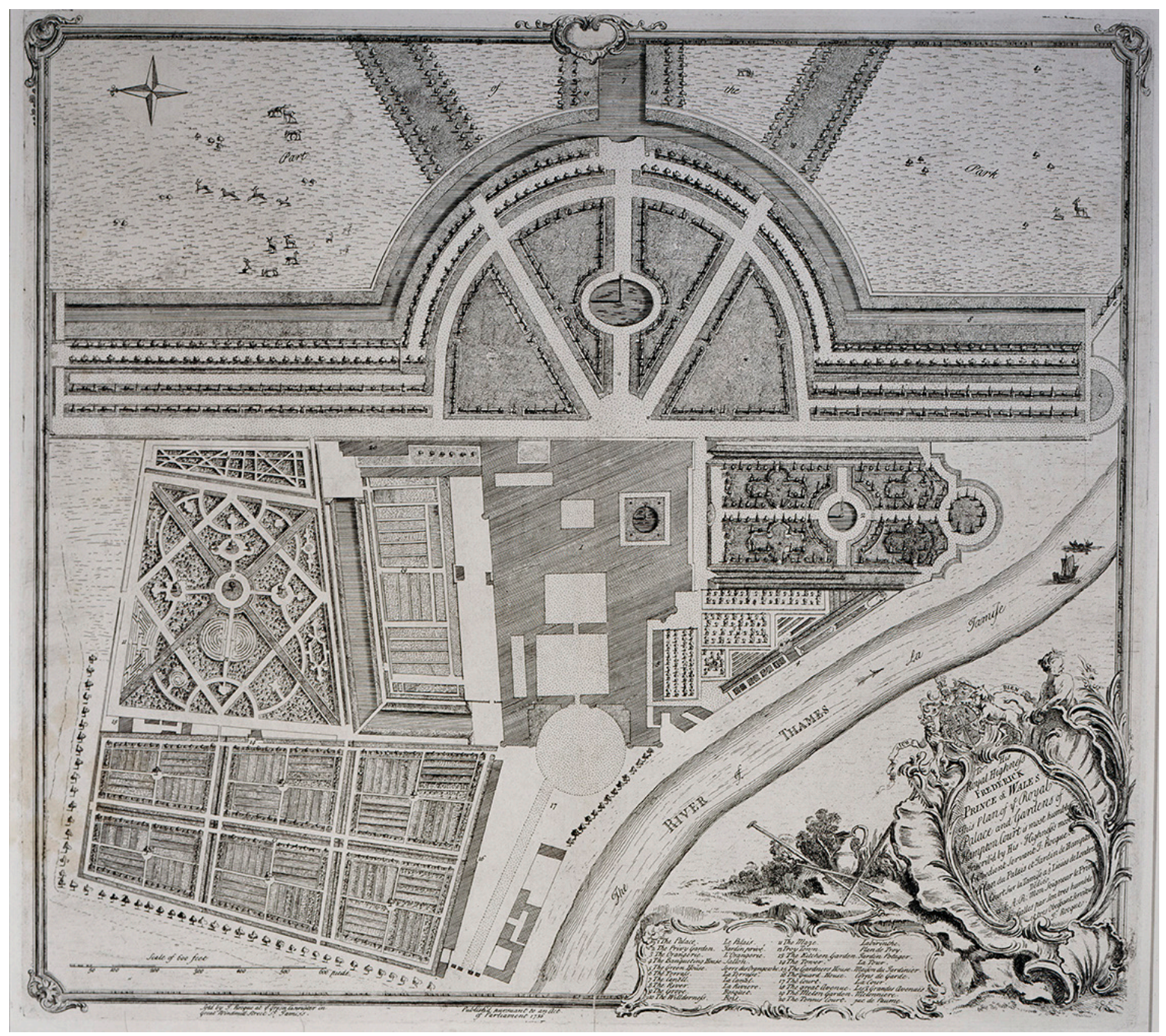

Figure 2.4: Plan of the palace and gardens of Hampton Court dedicated to Frederick, Prince of Wales (1707-51), John Rocque, 1736. @ Historic Royal Palaces.

nominally the job of the Surveyor of Gardens and Waters, though supervision was light, so in effect the Chief Gardener operated autonomously. One significant benefit was the occupation of Wilderness House, built in William III's reign on a wedge of ground between the Wilderness and the kitchen garden as the Master Gardener's residence (see Figure 1.4).

The garden attached to the Treasury, today the garden of 10 Downing Street adjacent to Horse Guards Parade, had been taken out of St. James's Park in 1736 (Figure 2.5), and was looked after by the gardener at St. James's for $£ 40$ per annum. When the gardener died in 1753 George Lowe had been awarded the keeping. ${ }^{25}$

Greening too was given a specific warrant for this garden, and so Brown carried on looking after it, but, receiving no payment, he wrote to the Treasury in November 1766:

Mr Brown presents his best respects to Mr: Lownds and begs the favour of him to enform him in what manner he is to be paid for Keeping the Treasury Garden \& the Kitchen Garden at Windsor. ${ }^{26}$

The following day Brown bumped into Greening, who had been at the Treasury Garden. Brown wrote that Greening, 'the Person who had the Place I now have ... told me to my great Surprise that he had been at the

${ }^{25}$ TNA, WORK 6/13, p. 76; warrant of 22 February 1753.

26 TNA, WORK 6/13, p. 99; warrant of 4 December 1758; TNA, T 1/455/412-413. 


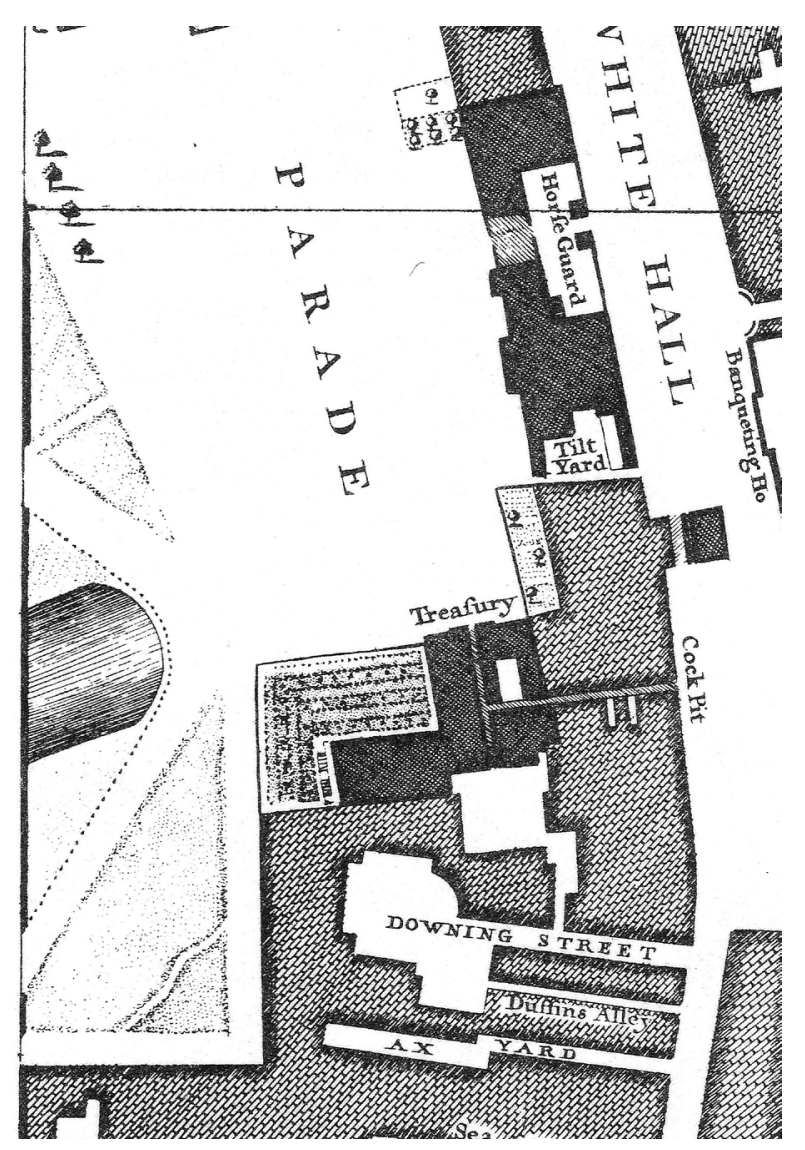

Figure 2.5: Detail from A Plan of the Cities of London, John Rocque, 1746, showing the Treasury garden. Copyright David Jacques, CC BY-NC 4.0.

Treasury Garden to do something for Lady Dalkeith, I only answerd that is very od[d] indeed .....27 Over a year later Brown had still not received any payment, though he had been paying his own men for three and half years. ${ }^{28}$ The Office of Works insisted that Brown had never had a warrant for Treasury Garden, as Greening had, and it was not until 1768 that Brown eventually received his warrant. ${ }^{29}$ Brown had been told that the kitchen garden at Windsor was also part of his duties, and so he had been laying out money there too. The Board of Works pointed out that there was no warrant for Brown there either, though they did admit that: 'Tis true that Mr Low, and Mr Greening ... had some allowance made them there, which was particularly ordered by the Board of Treasury.'30 It is unclear whether Brown was reimbursed, but he was certainly not given a warrant as there was already one for the incumbent, John Kent. ${ }^{31}$

\section{Brown in the Office of Works, 1766}

Brown was not received with unalloyed joy at the Office of Works. Although the ageing Henry Flitcroft, Comptroller of the Works, would probably have been sympathetic, others were not. Thomas Worsley, the SurveyorGeneral, and William Chambers, Architect of the Works, themselves put in place by the influence of Lord Bute, probably viewed Brown as a creature of the new Whigs who might well be ousted in the future by a Toryinclined king. Chambers was a man of principle, or, since our virtues are mostly but vices in disguise, ${ }^{32}$ he could

27 TNA, T $1 / 448 / 187-188$.

${ }_{28}$ TNA, T 1/468/330-331; letter of 15 February 1768.

${ }^{29}$ TNA, WORK 6/13, p. 233; warrant of 14 June 1768, backdated to 16 July 1764.

30 TNA, T 1/468/330-331, 15 February 1768.

31 TNA, WORK $8 / 08$, ff 49-53.

${ }^{32}$ FitzGibbon, C. (trans.) (1957). The maxims of the Duc de la Rochfoucauld (p. 31). London: Allan Wingate. 
be arrogant and confrontational. Having trained at the École des Arts in Paris and also having visited Rome, he perceived himself as a true professional with an international understanding of his art. Robert Adam wrote to his brother John about Chambers in 1755: 'He despises others as much as he admires his own talents which he shows with a slow and dignified air, conveying an idea of great wisdom.....33 At the Board of Works, however, Chambers always pedantically took the official line and proved to be an instinctive administrator.

In his relations with Brown, Chambers presumed an automatic superiority, and despised what he considered were Brown's simplistic ideas of nature peddled by one who had never been properly trained. Furthermore, Brown had been straying into architecture. Chambers discovered that they were actually in competition when both were asked to provide designs for Peper Harow, Surrey, by Lord Midleton in about $1763 .{ }^{34}$ When Brown was successful, the wariness turned into intense jealousy. Brown only took up his duties at Hampton Court after undertaking some of his tours in December 1764 and January 1765. Perhaps this, as much as the tensions with the architects, was why the Board of Works took eight months to acknowledge their new colleague:

Rec'd the Kings Warrt appointing Lancelot Browne Chief Gardiner at Hampton Court (in the room of Jno Greening) at £1107:6:0 Per Ann: \& 100£ Per Ann for raising Pine Apples \& an additional 100£ Per Ann for forced Fruits. ${ }^{35}$

These last-mentioned duties required purpose-made hothouses and bell glasses. Brown evidently also felt responsibility for the orange tree collection in the Upper Orangery. He needed, he soon told the Board of Works, repairs to hothouses, costed at about $£ 500$, and 'Garden pots, Bell Glasses, \& Orange Tubs' at about $£ 160 .{ }^{36}$ Getting nowhere, he addressed a memorandum directly to the Treasury Lords. This letter was referred back to the Board of Works for a report, and in October it informed the Treasury that 'repairs \&c. wanting in Hampton Court Gardens, will amount altogether to the sum of $£ 664: 3: 6 \mathrm{~d} \cdot{ }^{37}$ It evidently advised against the pots, bell glasses, and tubs, and the Board may in some senses have been right, as the previous Chief Gardener should have made good. The next month the Treasury issued a fiat 'for performing all the Repairs for the Master Gardiner at Hampton Court', but not authorising 'the additional Articles of Garden pots, Bell Glasses, \& Orange Tubs. ${ }^{38}$ However, in November, Brown provided a detailed explanation to the Treasury about the necessity for the pots and bell glasses for fulfilling the king's wishes. ${ }^{39}$ At last, in June 1766, the Treasury issued another fiat 'for supplying His Majestys Gardens at Hampton Court with some Garden pots, Bell Glasses \& Orange Tubs'.40 Although generally content with Wilderness House, the cellars suffered from damp, so in June 1769 Brown made an application to have a cellar and a kitchen added onto the house. The next month: 'Recd also their Lordships Fiat for repairs \& Alterations at the house of the Master Gardener at Hampton Court.'1

\section{The Great Vine and Other Fruit}

The Hampton Court gardens were renowned for their fruit, against walls and inside hothouses, in the Melon Ground and in the Kitchen Garden. ${ }^{42}$ Brown was assisted by Robert Lowe, nephew of his predecessor, who had effectively run the gardens in George Lowe's last illness. Robert, describing himself as 'used to fruit work', had petitioned unsuccessfully in 1758 to be given the place of his uncle who had 'bred him up and was a father to him. ${ }^{43}$ Brown inherited scores of orange trees, dating from William III's time, and passed them on to his successors in good order. One garden writer of the next century remarked that ' $\mathrm{t}]$ he largest collection in Britain is that at Hampton Court Palace, where two large apartments on the ground-floor, having only large glass

${ }_{33}$ Fleming, J. (1962). Robert Adam and his circle in Edinburgh and Rome (p. 160). London: John Murray.

${ }^{34}$ Stroud, D. (1975). Capability Brown (p. 236).

35 TNA, WORK 4/13, 1 March 1765.

36 TNA, T 1/451/420-421 \& WORK 4/13, 25 November 1765 ,

37 TNA, WORK 4/13, 18 October 1765.

38 TNA, WORK 4/13, 22 November 1765.

39 TNA, T 1/451, fol. 420-421, 16 November 1765.

40 TNA, WORK 4/13, 6 June 1766.

41 TNA, WORK 4/14, 14 July 1769 \& 19 January 1770.

42 Woudstra, J. (2016). Fruit cultivation in the royal gardens of Hampton Court Palace (1530-1842). Garden History, 4(4/2), Autumn 2016, forthcoming.

43 British Library, Additional MS 33055, f 270; quoted by Stroud, D. (1975). Capability Brown (p. 123). 
Twenty years after the Hampton Court vine was planted it was said to have produced 2,200 bunches, which weighed on an average a pound each. The stem was already $13 \mathrm{in}$. in girth, and the main branch $114 \mathrm{ft}$. long. ${ }^{47}$

In 1813 a tourist was informed that the vine was forty-three years old and had borne 2,278 bunches the year before. ${ }^{48}$

\section{The Reprimand}

Chambers became the Office of Works Comptroller in 1769 in place of Flitcroft, and started making formal inspections, visiting Hampton Court on the $21^{\text {st }}$ July 1770. No doubt surveying the gardens under Brown's care with a hyper-critical eye, he found them to be 'in ruinous condition', and, as a Principal Officer of the Works, felt it was his duty to see that Brown met the obligations stated in his contract. It was first decided to write 'a private notice less disagreeable than public admonition' ${ }^{49}$ Brown ignored this letter 'because I know both the Authors meaning, \& his Conduct on that Subject'. Finding this so after three months, Chambers had the Secretary to the Board, William Robinson, inform Brown that:

I am Order'd by the said Principal Officers of his Majesty's Works to require that you do forthwith put every part of the said Royal Gardens into proper Order in all particulars according to the Tenor of your Contract. $^{50}$

This drew a long response from Brown, written in astonishment and sorrow, but not in contrition:

Sir, I recd. your Letter, \& must acknowledge to you that I have lived long enough not to wonder at anything, therefore it did not surprise me. I believe I am the first King's Gardiner that the Board of Works ever interfered with ... I believe if any Body had a Right to have censured my Conduct it was the Surveyor of the Gardens, ... but you, Sir, have only done your duty, You will be so good as to inform the Gentlemen of the Board of Works That Pique I pity, That the Insolence of Office I Despise, That Ideal Power I laugh at, \& That real Power I will ever disarm by doing my Duty. I am

Sir your obedient Servant

Launcelot Brown. ${ }^{51}$

As Brown had 'disputed the authority of the Board of Works and treated our proceedings as the effects of arrogated Power and Insolence of Office, Chambers felt that matters needed to be taken to a higher level. A representation to the Treasury Lords, signed by Chambers and all the architectural officers, urged them to act. ${ }^{52}$ It was also pointed out that since the Lower Wilderness had been laid into the House Park, its acreage should be removed from the calculations on Brown's allowance. The Treasury Lords 'Ordered a Letter to be wrote to Mr Brown directing him to take care that the said gardens be kept in good repair and condition. ${ }^{53}$ With that, the matter was no more heard of.

The actual state of the gardens under Brown may be discerned from John Spyers's drawings (see Figure 3.3). The images of the Fountain Garden, the Privy Garden, and the Wilderness suggest that the hedges were in good order, but he had let the clipped greens grow out, allowing tufted tops on the yews. ${ }^{54}$ But, remembering the campaign against clipping initiated by Joseph Addison and Alexander Pope, no-one at that time would argue for the greens to be subjected to the shears and scissors.

\footnotetext{
47 Lysons, D. (1800). An historical account of those parishes in the county of Middlesex, which are not described in the environs of London (p. 72). London: T. Cadell Jun. \& W. Davies.

48 British Library, Add MS 6341, f 2v.

${ }^{49}$ TNA, T 1/475, ff 252-253, 16 November 1770.

50 TNA, WORK $1 / 4$, f 86v, Robinson to Brown, 26 October 1770.

51 TNA, WORK 1/5, f 87r, Brown to Robinson, 5 November 1770.

52 TNA, T 1/475/252-253, 20 November 1770.

53 TNA, WORK 4/14, 7 December 1770.

${ }^{54}$ Dedinken, M. \& Jacques, D. (2016). The Hampton Court albums of Catherine the Great (Album I, nos. 7647-7674). London: Fontanka.
} 


\section{St. James's Park}

St. James's Park was in the care of its Ranger, George Walpole, $3^{\text {rd }}$ Earl of Orford. It had received little attention over the years despite the large numbers of the public that used it. By long-standing arrangement between the Board of Works and the Ranger, the latter was paid $£ 80$ for 'The Sweeping and Cleaning of the Mall, and the Rolling, Keeping and Cleaning that Walk or any other Walks in the said Park. ${ }^{55}$ In 1770 the Treasury received a petition 'from the Principal Inhabitants of Westminster in the neighbourhood of St. James's Park complaining of a Nusance from that part of the park formerly called the Decoy ${ }^{56}$ The Treasury referred the matter to the Board of Works, which, with amazing alacrity, reported on this matter 'and other alterations \& repairs necessary to be done in the said Park and in the Front Court of the Queens Palace amounting in the whole to $£ 7894.5^{57}$ This was a huge sum, partly because of the extensive drainage culverts, but the Treasury Lords had no difficulty in issuing a fiat for the work. It was assumed by the newspapers that Brown would be the person to carry it out: 'Mr. Brown, the Engineer, commonly called Capability Brown, is to have the new modelling St. James's Park. ${ }^{58}$ This announcement gave a second reason for the changes:

The principal Point intended is to give a full View of Whitehall to the Queen's Palace, and also of Westminster Abbey, to effect which almost all the Trees on that Side will be taken away.

Brown even devised a plan, very possibly at this time (Figure 2.7). ${ }^{59}$ However, the Board had no intention of giving the work to Brown. The reprimand mentioned above may have been for the purest motives, but it was also a convenient device to undermine Brown's credibility with the Treasury Lords and to clear the way for the Board's own candidate for undertaking the works in the park - Thomas Robinson. In order for him to commence work, the Board of Works requested the Treasury to authorise an imprest of $£ 2,000$ in October $1770 .{ }^{60}$ Work got under way and in December the bills were coming in, including $£ 850$ from Robinson. ${ }^{61}$ Further imprests were authorised, most of it for Robinson's bills, and the books were approved in $1775 .{ }^{62}$

As with Brown's plan, The Mall and Birdcage Walk were retained, and the decoy with much planting around was eliminated. In other respects the new design was very different; in particular, the canal was retained, instead of being made a serpentine (Figure 2.8).

The problem of maintenance soon raised its head. Robinson pointed out that 490 English elm which he had planted just four years before were not being pruned, secured to tree stakes or watered, as they should have been. ${ }^{63}$ However sympathetic the Board might have been, this was not their responsibility and they had no leverage, except in one small respect. They paid the Ranger $£ 80$ per annum for keeping the paths. The Board thus wrote to Lord Orford a few weeks later informing him that 'frequent complaints have been made to them relative to the present very bad Condition of the Gravel, in the Mall \& the two side Walks. ${ }^{64}$

\section{Bad Feeling and the Paper War}

Brown may have felt resentment at the way he had been treated by his colleagues. In a surprising display of tit-for-tat he demanded that Chambers quit a half-acre kitchen garden area, part of the Royal Garden, off Tennis Court Lane. This provoked a pained memorial to the Treasury Lords pleading that, since he had no other ground at Hampton Court on which to grow fruit and vegetables during his stays at Hampton Court, it

55 TNA, WORK 6/8, ff 209-210, 7 February 1763.

56 TNA, WORK 4/14, 4 May 1770.

57 TNA, WORK 4/14, 18 May 1770.

58 Public Advertiser, 6 September 1770.

59 Stroud, D. (1975). Capability Brown (plate 54a).

60 TNA, WORK, 4/13, 12 October 1770.

61 TNA, WORK 4/13, 21 December 1770.

62 TNA, WORK 4/13, 27 October 1775.

63 TNA, WORK $1 / 5$, f 19r, 14 May 1779.

${ }_{64}$ TNA, WORK 1/5, f 20r, 23 July 1779. 


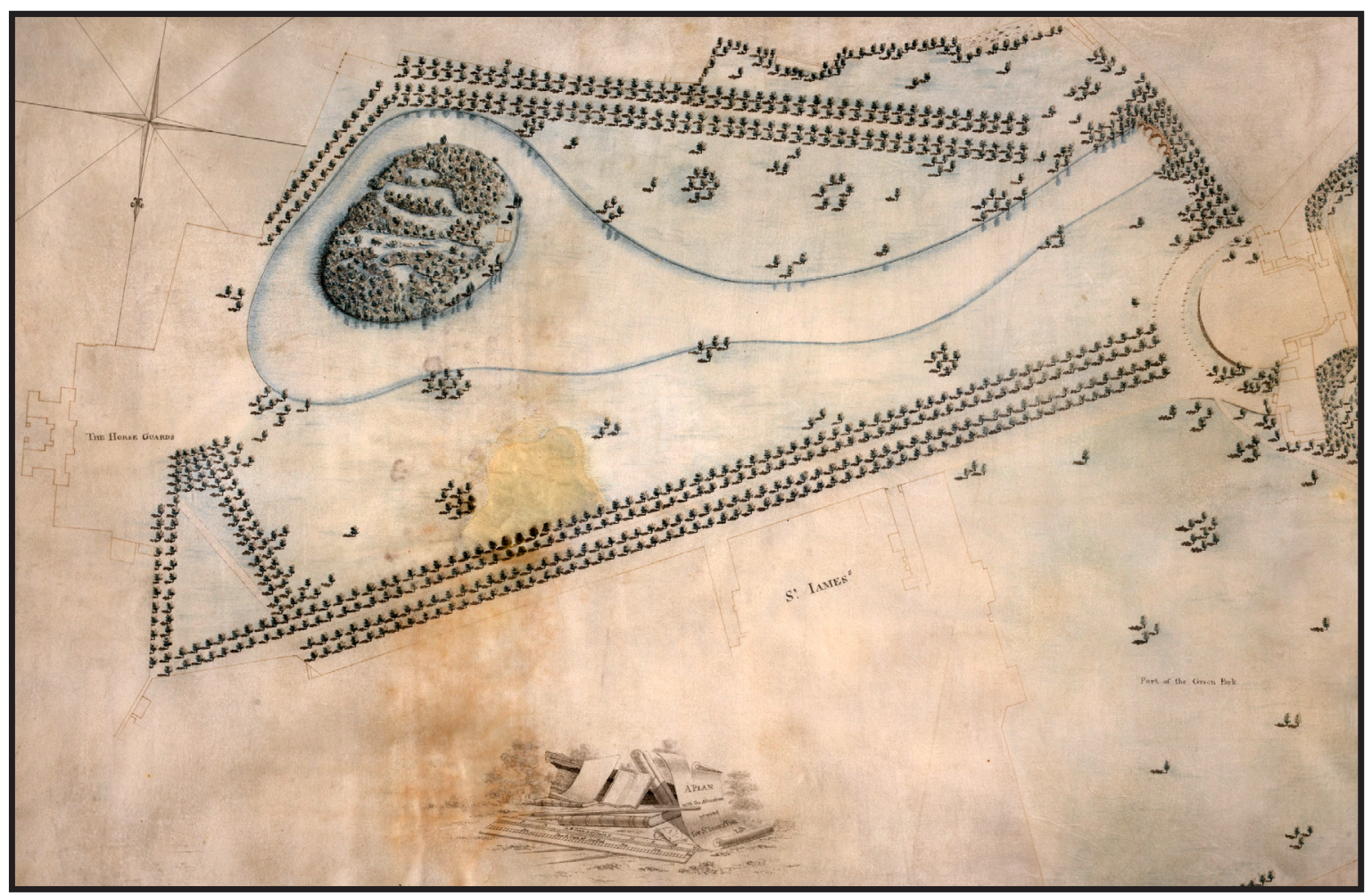

Figure 2.7: A Plan with the Alterations proposed for St. James's Park, Lancelot 'Capability' Brown, 1770. Source: Yale Center for British Art, Paul Mellon Collection.

Figure 2.8: A View of the Encampment of the Guards in St. James's Park, Thomas Davies, 1780. Copyright The British Library Board; Maps K.Top.26.7.d.3. Reproduced with permission.

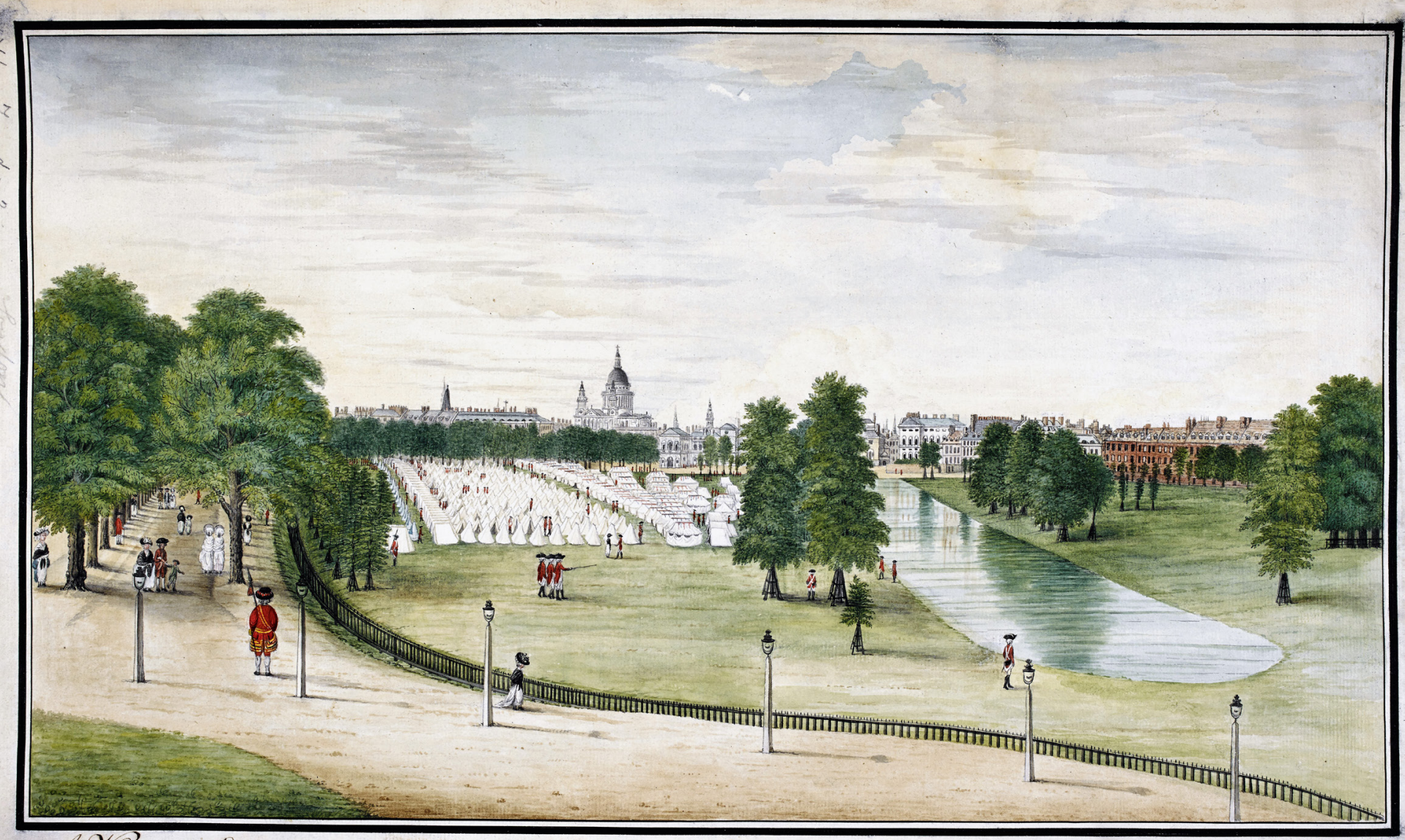

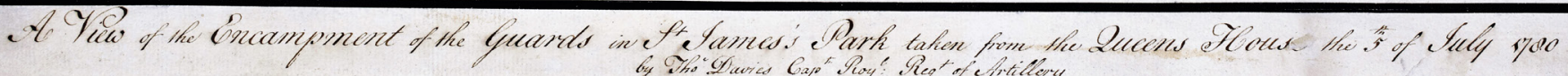


was a great convenience to him, as it had been to Flitcroft before him. ${ }^{65}$ Chambers appears to have kept this garden on, finally being required, but not by Brown, to hand over the keys in $1783 .{ }^{66}$

Brown had compensations. One was being asked in 1770 to design Clive of India's new house at Claremont, and to reform the grounds there. Another was the discovery that the Board had omitted to inform him that John Greening had been appointed to maintain the Maestricht Garden at Windsor, and that he, Brown, had a right to the same. Although the Maestricht Garden had been abandoned in the 1730s, somehow the warrants maintained the fiction of its continued care - or maybe it was the fruit garden adjacent that was meant. Brown must have quickly repaired relations with the Treasury Lords, for he applied to them for the $£ 30$ allowance and they, despite delay from the Board, directed that it should be paid. ${ }^{67}$

At the same time Brown applied to the Treasury for the Board to be instructed over 'some Forcing frames may be put in Order, and a new Stove made for raising Pine Aples and to fit up part of the Old one for raising Strawberries and Cherrys. ${ }^{68}$ After the usual delay from the Board, the Treasury instructed it to carry out repairs 'to the Glass cases and forcing frames as desired by Mr Brown. ${ }^{69}$ Brown returned to the matter of the new pine house and repairs to the old one in $1777 .^{70}$ The Treasury eventually sent a warrant to the Board to require them to build one..$^{71}$

Meanwhile, Chambers had sat down to compose his Dissertation on Oriental Gardening. He no doubt had a different conception of ornamental gardening from Brown, but it was his high-handed attack on the gardening profession that struck most readers. For example:

Is it not singular then, that an Art which a considerable part of our enjoyments is so universally connected, should have no regular professors in our quarter of the world? Upon the continent it is a collateral branch of the Architect's employment; ... in this island, it is abandoned to kitchen gardeners, well skilled in the culture of sallads, but little acquainted with the principles of Ornamental Gardening. It cannot be expected that men, uneducated, and doomed by their condition to waste the vigour of life in hard labour, should ever go far in so refined, so difficult a pursuit. ${ }^{72}$

Such comments were interpreted by some as a personal attack on Brown. Further comments such as 'peasants emerge from the melon grounds to take the periwig, and turn professors' could easily be interpreted as spiteful reminders of Brown's modest origins. ${ }^{73}$ The Dissertation was thought by some 'to avert his royal Majestie's attachment from the plan on which his garden at Richmond has been improved. ${ }^{74}$ Others thought it stemmed from the frustration of Brown obtaining the commission at Claremont. ${ }^{75}$ Horace Walpole asserted that it was 'more extravagant than the worst Chinese paper, and ... written in wild revenge against Brown. ${ }^{\text {?6 }}$

If Chambers could be made to seem ridiculous then the artistic credibility of the Tory Court appointees would be undermined. The Dissertation provided an ideal opportunity for the Whigs, and so, spurred on by Walpole, William Mason wrote a mock-heroic reply. An Heroic Epistle to Sir William Chambers, Knight appeared in January 1773 just as London was filling up for the winter season. A short preface composed in irony reminded readers of the purpose of the Dissertation:

It is the author's professed aim in extolling the taste of the Chinese, to condemn that mean and paltry manner that Kent introduced; which Southcote, Hamilton and Brown followed, and which, to our

\footnotetext{
${ }^{65}$ TNA, T 1/482/86-87, 7 June 1771.

${ }_{66}$ TNA, WORK $1 / 5$, f 57v, April 1783.

67 TNA, WORK 4/14, 8 \& 15 November 1771 \& 28 February 1772.

68 TNA, WORK 4/14, 7 February 1772.

69 TNA, WORK, 4/15, 12 February 1773.

70 TNA, WORK 4/15, 27 June 1777.

71 TNA, WORK 4/15, 10 December 1779.

${ }^{72}$ Chambers, W. (1772). A dissertation on oriental gardening (p. iii). London: W. Griffin \& others.

${ }^{73}$ Chambers, W. (1772). Dissertation (p. 13).

${ }_{74}$ Monthly Review, XLVII, August 1772, 137; cited in Harris, J. Chambers (p. 158).

75 Walpole, H. (1876). Anecdotes of painting in England... with additions by the Rev. James Dalloway (3 Vols, III, p. 106), edited by R. Wornum. London: Chatto \& Windus.

${ }^{76}$ Walpole, H. (1955). Correspondence (Vol. 34). New Haven: Yale. Walpole to William Mason, 25 May 1772.
} 
national disgrace, is called the English style of gardening. He proves ... that Nature herself is incapable of pleasing, without the assistance of Art, and that too of the most luxuriant kind.

In one passage Chambers was invited to Richmond Gardens so that readers could imagine what he would have done:

[line 53] Come then, prolific Art, and with thee bring

The charms that rise from thy exhaustless spring;

To Richmond come, for see, untutor'd Brown

Destroys those wonders which were once thy own.

Lo, from his melon-ground the peasant slave

Has rudely rush'd, and levell'd Merlin's Cave;

Knock'd down the waxen Wizzard, seiz'd his wand,

Transformed to lawn what late was Fairy land;

And marr'd, with impious hand, each sweet design

Of Stephen Duck, and good Queen Caroline.

Haste, bid yon livelong Terras re-ascend,

Replace each vista, straighten every bend;

Shut out the Thames; shall that ignoble thing

Approach the presence of great Ocean's King?

No! let Barbaric glories feast his eyes,

August Pagodas round his palace rise,

And finish'd Richmond open to his view,

A work to wonder at, perhaps a Kew.

The Heroic Epistle was undeniably funny and became one of the century's most popular poems.

Chambers maintained a critical eye on Brown, and reported to Worsley, the Surveyor, in 1774 that 'Master Brown has now put padlocks upon the Wilderness at Hampton Court where he breeds turkeys and Pea fowls'. Turkeys were a popular meat at this time, but padlocking the Wilderness would be overreaching his authority unless he had been doing so at the request of George III. Chambers was contemplating another reprimand and, as he thought it was his 'duty' to do so, took the matter up with the king, without much response. He recollected that he and his colleagues 'were so ill supported when last we endeavoured to make him do his duty, that there is no encouragement for a Second Attempt. ${ }^{77}$ Chambers looked for opportunities to reprimand Brown again, and in 1779 returned to one of his favourite themes:

the planting Trees close to the External Walls of the Palace has been very prejudicial to the same. They desire therefore that you would cause them to be removed \& not permit any Trees in future to be planted nearer than three feet from the Walls nor any Climbers creepers or other plants to be nail'd to the Walls on any Account. ${ }^{78}$

Chambers's appointment to the Surveyorship in 1782 might have been problematic for Brown, though as he now answered to the Lord Chamberlain he may in practice have been insulated from further attacks. By this time the sparring between these two adversaries had died down after the madness of the Dissertation and the Heroic Epistle. Brown died unexpectedly in February 1783. His successor at Hampton Court was Thomas Haverfield, a son of John, who seems to have led a quieter life altogether.

Although Brown had yearned for an official position, it gave him much trouble in the form of the confrontational William Chambers and the Robinson brothers. He received absolutely no favours from the Board of Works, and had to fight for allowances, warrants, and the Board's architectural work on the gardens, such as hothouses. He was pointedly passed over for alterations at the Queen's House and St. James's Park by someone of much less capacity. Nevertheless, he was secure in Wilderness House, thanks to the benevolent attitude of

\footnotetext{
77 British Library, Add.MS, 41135, f 39, Sir William Chambers to Thomas Worsley, 13 September 1774, information from Todd Longstaffe-Gowan.

${ }^{78}$ TNA, WORK 1/5, f 30v, 23 July 1779.
} 
many Treasury Lords who were his clients outside the walls of Hampton Court. His position as Chief Gardener to His Majesty may not have brought the rewards that he may have hoped for, but it bestowed some status, the house served as a family home, and he had a base for his extensive contracting business.

\section{Select Bibliography}

A select bibliography is available at the end of this volume, or at: https://doi.org/10.22599/CapabilityBrown.o 